\title{
Peertechz
}

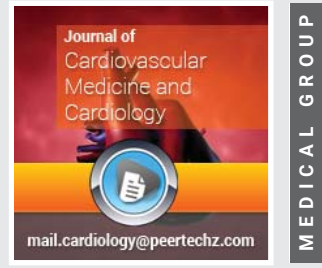

\section{Novel Applications of Anticoagulation with Bivalirudin in Cardiac Surgery}

\author{
R Pradeep Kumar ${ }^{1 *}$, S Murugan², Rajkumar MC², Joseph \\ Chacko $^{3}$, Jasmine ${ }^{4}$, Arun Vijayakumar ${ }^{5}$ and A Nazer ${ }^{6}$ \\ ${ }^{1}$ Professor \& Senior Consultant Cardiothoracic Surgeon, Division of Cardiothoracic Surgery, \\ Travancore Heart Institute and Medical College, SUT Royal and PRS Group, India \\ ${ }^{2}$ Junior Consultant, Director Surgical Division, Travancore Heart Institute and Medical College, SUT \\ Royal Group and PRS Group, Kerala India \\ ${ }^{3}$ Head of Perfusion Technology, Director Surgical Division, Travancore Heart Institute and Medical \\ College, SUT Royal Group and PRS Group, Kerala India \\ ${ }^{4} \mathrm{Sr}$ Perfusion Technologist, Director Surgical Division, Travancore Heart Institute and Medical College, \\ SUT Royal Group and PRS Group, Kerala India \\ ${ }^{5}$ Chief Cardiac Anesthetist, Director Surgical Division, Travancore Heart Institute and Medical College, \\ SUT Royal Group and PRS Group, Kerala India \\ ${ }^{6}$ Professor and Sr Consultant and Director Surgical Division, Travancore Heart Institute and Medical \\ College, SUT Royal Group and PRS Group, Kerala, India
}

Received: 21 March, 2018

Accepted: 24 November, 2020

Published: 25 November, 2020

*Corresponding author: Radhakrishnan Pradeep Kumar, Professor \& Senior Consultant Cardiothoracic Surgeon, Division of Cardiothoracic Surgery, Travancore Heart Institute and Medical College, SUT Royal and PRS Group, India, Tel: 9895270192 ;

E-mail: rpksai@hotmail.com

Keywords: Bivalirudin; OPCAB: Off pump coronary artery bypass; TAR: Total arterial revascularization; Nonresectional mitral valve repair; HIT: Heparin induced thrombocytopenia; LVAD: Left ventricular assist device; ECMO: Extra corporeal membrane oxygenation

https://www.peertechz.com

Check for updates
We have successfully done off pump total arterial coronary surgery (CABG) using Bivalirudin in a patient awaiting liver transplantation with history of variceal bleed and thrombocytopenia and also in another patient we used Bivalirudin for traumatic mitral regurgitation and heparin induced thrombocytopenia , who underwent mitral valve repair successfully.

\section{Short case summary}

First was a patient 46 yr old male awaiting liver transplantation at AIMS Cochin, diagnosed to have triple vessel disease, thrombocytopenia and bilateral severe varicose veins. He had history of multiple variceal bleed and anemia. Off pump (beating heart) total arterial revascularization, with fully skeletonized harvest of bilateral internal mammary arteries and bilateral radial arteries were done. Bivalirudin was used for the procedure. The following grafts were fashioned using total arterial off pump coronary artery bypass technique (TAR-OPCAB). LIMA - LAD, RIMA to PDA with extension of RIMA to reach distal PDA being done with EEA of right radial artery segment to RIMA. LIMA -LRA -Y (composite graft) was fashioned to D1, OMB1 and OMB2.Mid patch plasty after endarterectomy was done with radial artery segment.

The second was a young male 28 years old admitted with history of RTA at Nagercoil and blunt trauma. He was diagnosed to have superior mesenteric thrombosis. ECHO evaluation in ICU showed severe traumatic mitral regurgitation. He was diagnosed to have HIT. Successful repair of mitral valve was done with creation of artificial neo chordae using PTFE sutures, leaflet tear plication and reinforcement with true size $\mathrm{CE}$ annuloplasty ring. Bivalirudin was used in bypass.

\section{Technique}

Bivalirudin was the anticoagulant used during cardiopulmonary bypass. The extracorporeal circuit consisted of a roller pump, a Capiox SX oxygenator (Terumo Cardiovascular Systems, Ann Arbor, MI), and a hard plastic reservoir. No heparin was used. The pump priming solution consisted of $2000 \mathrm{~mL}$ of plasmalyte and $50 \mathrm{mEq}$ of bicarbonate. 
Blood cardioplegia was given in antetrograde manner [14]. OPCAB dosage was Bivalirudin ( $0.75 \mathrm{mg} / \mathrm{kg}$ bolus, 1.75 $\mathrm{mg} / \mathrm{kg} / \mathrm{h}$ infusion).Bivalirudin for on pump procedure as in second case was administered intravenously as a $1.25 \mathrm{mg} / \mathrm{kg}$ bolus, followed by a continuous infusion at $2.75 \mathrm{mg} \cdot \mathrm{kg}^{-1} \cdot \mathrm{h}^{-}$ ${ }^{(1)}$.Bivalirudin was added to the pump priming solution also. The Activated Clotting Time (ACT) was measured every 15 to 3ominutes. Additional boluses were given as needed with the infusion rate being adjusted to maintain an ACT of 500 to 600 seconds. TAR OPCAB was done for the first patient using off pump technique. In the second case non resection graded neochordal reconstruction (Dynamic Indian Correction) was employed with valve being approached via the superior septal approach, using on pump technique with true size 28 Physio II ring $[5,6]$. No mitral regurgitation post repair was noted using Intraop TEE.

\section{Discussion}

Mechanical destruction in bypass circuit with hemodilution accounts for the primary reduction in platelet count during a cardiac surgical procedure. Reduction of up to $30 \%$ from initial levels are noted which reach upto $40-60 \%$ of initial values on the second or third postoperative day. Drug induced thrombocytopenia, IABP, sepsis, post transfusion purpura are additional contributory factors. A direct thrombin inhibitor is indicated when HIT (heparin induced thrombocytopenia) is suspected. Heparin in HIT type II could result in bleeding, thromboembolism and death.

Bivalirudin (Angiomax) is a direct thrombin inhibitor. This is a semi synthetic derivative of hirudin which can inactivate both unbound and fibrin-bound thrombin. Elimination route is mainly renal and has a short duration of action, with safety for use being documented in patients with HIT type II also. Heparin has to be discontinued.HIT is more frequent with the use of unfractionated heparins. Bleeding is noted in $53 \%$, embolic complications in $44 \%$ and death in $33 \%$. HIT antibodies (polysaccharide-PF4complex) may be negative. In $25 \%$ of cases, the antibody that causes HIT does not recognize the polysaccharide-PF4 complex.

HIT can be differentiated from thrombocytopenia due to GPIIb/IIIa inhibitor therapy by time course and severity of thrombocytopenia. Thrombocytopenia due to HIT is noted between days 5 and 14 of heparin therapy. The exception to this rule is prior exposure to heparin in the previous 3 months, in which case the fall in platelet count is earlier. With presence of Petechiae or gingival hemorrhage diagnoses other than HIT should be thought of.

- Glycoprotein (GP) IIb/III a receptor inhibitors abciximab, tirofiban, and eptifibatide and heparin. Counts fall early. Check 2-4 hours after treatment has commenced.

- Pseudo thrombocytopenia occurs due to platelet clumping in tubes containing ethylendiaminetetraacetic acid as an anticoagulant.
- Ticlopidine, 2 to 12 weeks of the initiation of therapy

- Clopidogrel - first 2 weeks of use

- Alternatives for heparin-induced thrombocytopenia type II .Effective anticoagulation with Bivalirudin, Available direct thrombin inhibitors include recombinant hirudin (lepirudin), Argatroban, and Bivalirudin (Angiomax). Of these lepirudin is most frequently used. These do not cross react with heparin antibodies. The disadvantages include lack of an antidote, less experience and greater expenses. Lepirudin lacks a standardized monitoring of anticoagulant activity during $\mathrm{CPB}$. Its relatively long half-life (80 minutes) aggravates the bleeding risk. Argatroban has recently been used with success during CPB in Japan. This drug not available for use in the United States. It has a short half-life (30 minutes) .Anticoagulation assessment can be done using ACT.

Advantages of Bivalirudin include its short half-life (25 minutes), easy monitoring of anticoagulation using ACT,PT,APTT, thrombin time all of which rise linearly with dosage. Renal and intravascular proteolysis is the major methods of drug clearance from the body. Dose of Bivalirudin can be adjusted during CPB to keep the ACT between 500 and 600 seconds, using intravenous boluses in addition to the continuous infusion. During surgery no clot formation was noted in the CPB circuit, tubing or operating field and the postoperative bleeding was acceptable.

The Ecarin Clotting Time (ECT) correlates strongly (R2 $1 / 4$ 0.91) with therapeutic bivalirudin concentrations but is not commonly available as a point of-care test [8] .Although not as accurate as the ECT, the more commonly available celite-ACT was found to have an acceptable correlation with ECT-determined bivalirudin concentration (R2 $1 / 4$ 0.93) [9]. Bivalirudin dosing in the CHOOSE-ON and EVOLUTION-ON trials included a loading dose of $1.0 \mathrm{mg} / \mathrm{kg}$, infusion of $2.5 \mathrm{mg} \mathrm{kg}$ $\mathrm{h}$, and pump prime of $50 \mathrm{mg}$. The adequacy of anticoagulation was monitored using 2.5 times the baseline ACT $[10,11]$. In offpump coronary artery surgery, established protocols can be easily translated and bivalirudin has the potential for a more important role in the future. Through a triple mechanism of action-inhibition of plasma thrombin, clot bound thrombin, and collagen-induced platelet activation-bivalirudin may perform better than heparin by attenuating the immediate postoperative prothrombotic state and thus positively impacting the early coronary graft patency after off-pump coronary artery bypass grafting

We conclude that Bivalirudin is a safe alternative to heparin for anticoagulation during $\mathrm{CPB}$ and in off pump procedures in cardiac operations. For PCI Argatroban has been approved for use in patients with HIT $[12,13]$. We would like to add that use off pump (beating heart technique) and of BIMA -of fully skeletonized internal mammary arteries bilaterally and radial arteries avoids the need for antiplatelet agents in the postoperative period [7] and use of Bivalirudin in these patients is safe and is extremely useful in the subset of patient awaiting liver transplant or those with HIT. Anticoagulation strategy

Citation: Kumar RP, Murugan S, Rajkumar MC, Chacko J, Jasmine, et al. (2020) Novel Applications of Anticoagulation with Bivalirudin in Cardiac Surgery. $J$ 
using the off-label use of a continuous infusion of bivalirudin in a case of severe hypoxemic and hypercarbic respiratory failure caused by COVID-19 requiring venovenous ECMO has been reported [14]. First case series on the use of bivalirudin as an alternative to heparin in six hemodynamically stable patients with a total of ten hospitalizations for Heart Mate II LVAD thrombosis has also been reported and the spectrum of indications are expanding [15].

\section{References}

1. Brieger DV, MakK.H, Kotlke-Marchant K, Topol EJ (1998) Heparin Induced thrombocytopenia. Am Coll Cardiol 31: 1449-1459.

2. Aouifı A, Blanc P, Pinou V, Bastien OH, Ffrench P, et al. (2001) Cardiac surgery with cardiopulmonary bypass in patients with type II heparin induced thrombocytopenia. Ann Thorac Surg 71: 678-683. Link: https://bit.ly/3nUOndd

3. Furukawa K, Ohteki H, Hirakata K, Narita Y, Koga S (2001) The use of Argatroban as an anticoagulant for cardiopulmonary bypass in cardiac operations. $J$ Thorac Cardiovas Surg 122: 1255-1256. Link: https://bit.ly/3pXu5kP

4. Merry AF, Raudkivi PJ, Middleton NG, Dougall MMCJ, Nanad P, et al. Bivalirudin versus heparin and protamine in off-pump coronary artery bypass surgery. Ann Thorac Surgery 77: 925-931. Link: https://bit.ly/3I0LIgb

5. Kumar PR, Nazer YA (2018) New Dynamic Indian Correction for Mitral Valve repairs- non resectional neochordal graded reconstruction. Asian Annals of Cardiac Surgery.

6. Pradeep Kumar R, Nazer YA (2018) Video technique on New Dynamic Indian Correction for mitral valve repair. submitted to CTS net video session.

7. Pradeep Kumar R, Rajakumar, Murugan, Nazer YA (2018) Total Arteria Revascularization: Bypassing Antediluvian Notions. EC cardiology 4: 167-169. Link: https://bit.ly/3I3ls3w
8. Koster A, Spiess B, Chew DP, Krabatsch T, Tambeur L, et al. (2004) Effectiveness of bivalirudin as a replacement for heparin during cardiopulmonary bypass in patients undergoing coronary artery bypass grafting. Am J Cardiol 93: 356359. Link: https://bit.ly/2KCcAXh

9. Zucker ML, Koster A, Prats J, Laduca FM (2002) Sensitivity of a modified ACT Test to levels of bivalirudin used during cardiac surgery. J Extra Corpor Tech 37: 364-368. Link: https://bit.ly/2HtkFw7

10. Dyke CM, Smedira NG, Koster AA, Aroson S, Mc carthy CCP, et al. (2006) Comparison of Bivalirudin to heparin with protamine reversal in patients undergoing cardiac surgery with cardiopulmonary bypass: The Evolution On study. J Thorac Cardiovas Surg 131: 5339. Link: https://bit.ly/39dPMY2

11. Stratmann G, de Silva AM, Tseng EE, Julie H, Michel B, et al. (2004) Reversal of direct thrombin inhibition after cardiopulmonary bypass in a patient with heparin induced thrombocytopenia. .Anaesth Anlag 98:1635-1639. Link: https://bit.ly/360q86Y

12. Pishko AM, Cuker A (2017) Heparin-induced thrombocytopenia in cardiac surgery patients. Semin Thromb Hemost. 43: 691-698. Link: https://bit.ly/2KBI7so

13. Hassen K, Maccaroni MR, Sabry H, Mukherjee S, Serumadar S, et al. (2018) Management of refractory bleeding post-cardiopulmonary bypass in an acute heparin-induced thrombocytopenia type II renal failure patient who underwent urgent cardiac surgery with bivalirudin (Angiox) anticoagulation. Perfusion 33: 235-240. Link: https://bit.ly/3m0JI8Z

14. Seelhammer TG, Rowse P, Yalamuri S (2020) Bivalirudin for Maintenance Anticoagulation during Venovenous Extracorporeal Membrane Oxygenation for COVID -19. J Cardiothoracic Vasc Anesth. Link: https://bit.ly/39nJsxt

15. Rimans J, Sylvester KW, Connors JM (2017) Direct Thrombin inhibitor for LVAD thrombosis A Closer Look Clinc Apl Throm Hemost 23: 405-409. Link: https://bit.ly/363AymJ
Discover a bigger Impact and Visibility of your article publication with Peertechz Publications

Copyright: @ 2020 Kumar RP, et al. This is an open-access article distributed under the terms of the Creative Commons Attribution License, which permits unrestricted use distribution, and reproduction in any medium, provided the original author and source are credited.

Citation: Kumar RP, Murugan S, Rajkumar MC, Chacko J, Jasmine, et al. (2020) Novel Applications of Anticoagulation with Bivalirudin in Cardiac Surgery. $J$ Cardiovasc Med Cardiol 7(4): 293-295. DOI: https://dx.doi.org/10.17352/2455-2976.000155 